$\begin{array}{ll}\text { Abstracta Iranica } & \begin{array}{l}\text { Abstracta Iranica } \\ \text { Revue bibliographique pour le domaine irano-aryen }\end{array} \\ & \text { Volume } 25 \mid \mathbf{2 0 0 4} \\ \text { Comptes rendus des publications de } \mathbf{2 0 0 2}\end{array}$

\title{
Iran : Nouvelles identités d'une république. Paris, Belin, 2002, 223 p.
}

Rédaction

\section{OpenEdition}

1 Journals

Édition électronique

URL : http://journals.openedition.org/abstractairanica/5218

DOI : 10.4000/abstractairanica. 5218

ISSN : 1961-960X

Éditeur :

CNRS (UMR 7528 Mondes iraniens et indiens), Éditions de l'IFRI

Édition imprimée

Date de publication : 15 mai 2004

ISSN : 0240-8910

Référence électronique

Rédaction, «Iran : Nouvelles identités d'une république. Paris, Belin, 2002, 223 p. », Abstracta Iranica [En ligne], Volume 25 | 2004, document 348, mis en ligne le 15 mars 2006, consulté le 25 septembre 2020. URL : http://journals.openedition.org/abstractairanica/5218; DOI : https://doi.org/10.4000/ abstractairanica. 5218

Ce document a été généré automatiquement le 25 septembre 2020.

Tous droits réservés 


\section{Iran : Nouvelles identités d'une république. Paris, Belin, 2002, 223 p.}

\section{Rédaction}

Cet petit ouvrage présente dans une forme accessible un tableau de l'Iran actuel du point de vue culturel, social, politique, économique, en mettant en évidence, à partir des travaux récents des spécialistes des domaines concernés, les nouveaux caractères de la société iranienne après 25 ans de République islamique. Les modèles anciens n'ont pas été abolis, mais ils ont été profondément recomposés. Il n'est plus possible de comprendre ce pays sans prendre en compte ses nouvelles identités.

\section{INDEX}

Thèmes : 15.1. Iran

\section{AUTEURS}

\section{RÉDACTION}

Directeur de la revue et secrétariats (Paris et Téhéran) 